\title{
CIC/DUX4 Fusion Protein
}

National Cancer Institute

\section{Source}

National Cancer Institute. CICIDUX4 Fusion Protein. NCI Thesaurus. Code C139676.

A fusion protein encoded by the CIC/DUX4 fusion gene. This protein is comprised of the majority of the protein capicua homolog, including the DNA-binding high-mobility group (HMG)-box and 15 of 16 putative MAPK phosphorylation sites, fused to the C-terminus of double homeobox protein 4 , which results in the loss of both of its DNA-binding homeodomains. 